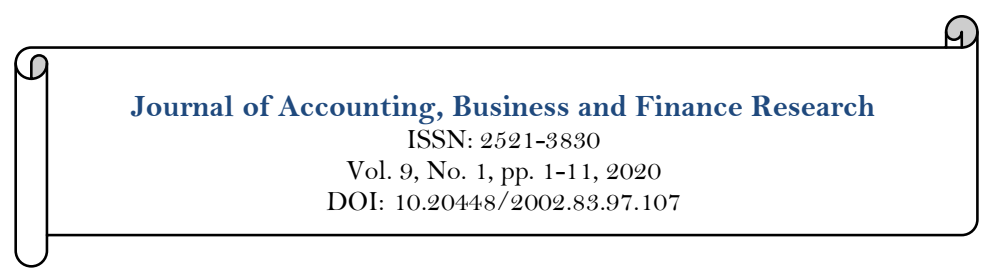

Check for

\title{
E-Banking Payment Instruments and Deposit Money Banks' Performance in Nigeria: An Empirical Investigation
}

\author{
Stephen E. Ughulu ${ }^{\text {* }}$ \\ Abraham O. Agbonkhese ${ }^{2}$ \\ 'Department of Banking and Finance, Igbinedion University, Okada, Edo State, Nigeria. \\ Email: stephenughulu46@gmail.com \\ ${ }^{2}$ Department of Economics, Admiralty University of Nigeria, Ibusa, Delta State, Nigeria.
}

\begin{tabular}{|c|c|}
\hline Abstract & \\
\hline $\begin{array}{l}\text { This paper carried out an empirical investigation of the impact of e-banking } \\
\text { payment instruments on the performance of Deposit Money Banks (DMBs) } \\
\text { in Nigeria for the period } 2009 \text { to } 2017 \text {. The major findings of the paper } \\
\text { showed that ATM exerted a negative effect on ROA but was significant at } \\
\text { the } 5 \% \text { level; exerted a positive effect on ROE at the } 5 \% \text { level, and negative } \\
\text { effect on NPM at the } 5 \% \text { level. POS exerted a negative effect on ROE but } \\
\text { was significant at the } 5 \% \text { level; it exerted positive and significant impact on } \\
\text { NPM; WB exerted positive and significant effect on ROA and NPM at the } \\
5 \% \text { level. These findings were robust and impressive as the value of the } \\
\text { ECM(-1), -O.3988, -O.4857, -O.5863 and -22682 appeared with the right } \\
\text { signs. The coefficients of determination, } R^{2} \text {, in the three columns showed that } \\
\text { all the independent variables accounted for over } 50 \% \text { fluctuations in the } \\
\text { dependent variables. The paper concluded that e-banking payment } \\
\text { instruments have great potentials in enhancing the performance of the } \\
\text { DMBs. It was therefore recommended that the DMBs make it a matter of } \\
\text { policy to continually upgrade the efficiency of these all-important instruments } \\
\text { to meet the expectations and satisfaction of their clients and hence } \\
\text { shareholders' wealth. }\end{array}$ & $\begin{array}{l}\text { Keywords: } \\
\text { E-Banking payment instruments } \\
\text { DMBs' performance } \\
\text { Nigeria. } \\
\text { JEL Classification: } \\
\text { G21. } \\
\text { Licensed: } \\
\text { This work is licensed under a } \\
\text { Creative Commons Attribution } 4.0 \\
\text { License. } \\
\text { Publisher: } \\
\text { Scientific Publishing Institute } \\
\text { Received: } 6 \text { January } 2020 \\
\text { Revised: } 10 \text { February } 2020 \\
\text { Accepted: } 19 \text { February } 2020 \\
\text { Published: } 2 \text { March } 2020\end{array}$ \\
\hline
\end{tabular}

Funding: This study received no specific financial support.

Competing Interests: The authors declare that they have no competing interests.

\section{Introduction}

Generally speaking, the banking industry is the most regulated and crucial in any economy since it mobilizes money from the excess economic units for on-lending to the insufficiency economic units for investment and consumption purposes. Thus, the banking system channels funds from savers to borrowers. This intermediation process determines, to a large extent, the efficient allocation of savings and invariably the performance of banks. It is, however, important to state at this outset that banks also carry out other noninterest income activities such as the deployment of electronic payment instruments to enhance their overall income. When these functions are simultaneously and efficiently and effectively performed, banks' profitability increases, their flow of funds rises in the process, and these would engender better quality service to customers and ultimately shooting up their financial performance.

Until relatively recently, banks were confronted with the enormous problems of satisfying customers' needs in the areas of deposit and payment functions. These culminated in long delays in the settlement of cheques among banks, unnecessary time consumed in banks as customers waited patiently in long queues for their turn, while mistakes resulting from manual work lead to frequent criminally-induced circumstances. 
Consequently, many customers became dissatisfied about the poor service delivery of banks and this resulted to loss of confidence in operations of the entire banks by the general public. To rectify these problems, experts and researchers went to work to find solutions to the problems that were seriously threatening banks' corporate existence and performance.

Accordingly, the e-banking system emerged in 1960, following the introduction of a machine capable of accepting cash or check deposit irrespective of time of day or night by Simjian who was then an American inventor and businessman. He convinced a New York City bank to install few of these automatic-deposit machines which were mostly patronized by prostitutes and gamblers who choose not to transact through cashiers directly (Floss, 2013). By the late 1960s, a larger part of the population showed interest in self-service and decided to give trial to automated banking, instead of trusting unfamiliar technologies. In 1967, a Scottish inventor (John Shepherd-Barron) invented the first automated teller machine (ATM), which was mounted at Barclays Bank branch in Enfield High Street. Different from the present day modern ATMs, ShepherdBarron's ATM used paper vouchers printed with radioactive ink such that the machine can easily read them instead of plastic cards. The first automated banking machine in the United States of America was invented by a Dallas engineer and former professional baseball player known as Donald Wetzel. Wetzel's invented machine made use of plastic cards just as experienced today. A Chemical Bank branch on Long Island was first to install Wetzel's machines in the month of September, 1967 (Bellis, 2019). As at today, over one million ATMs are installed close to banks and strategic business places across major cities and towns in Nigeria. The present-day machines sell many products such as tickets of airlines, movie down to medicine tickets (Floss, 2013). Other components of e-banking include point of sale (POS), web banking (WB), mobile banking (MB), etc.

This paper empirically examines the impact of e-banking payment instruments on the performance of DMBs in Nigeria from 2009 to 2017. In carrying this in-depth investigation, the fully modified ordinary least square (FMOLS) is deplored to analyze the secondary data obtained for the study. Other sections of the paper are structured as: Section II centers on literature review, Section III concerns the methodology, section IV presents data analysis and results interpretations, while section $\mathrm{V}$ gives the summary, conclusion and recommendations of the paper.

\section{Literature Review}

Plethora of prior studies exist on the effects of e-banking payment instruments (such as ATM, POS, WB, E-Mobile) on the performance of DMBs in Nigeria. Such studies have used different types of data and periods to conduct their research. This explains why the findings/results that emerged from such studies are mixed.

\subsection{Conceptual Issues \\ 2.1.1. Financial Performance}

In this paper, financial performance is measured by profitability ratios. These ratios display a bank's general efficacy and performance. Profitability ratios are tools of financial analysis because of their usefulness in the determination of the bank's bottom line. Application of profitability ratios as measurement of financial performance are crucial to managers and owners because it indicate a bank's aggregate efficiency and outcomes which are essential for decision making. Conventionally, profitability ratios are majorly of two parts - margins and returns. Profitability ratios concerned with margins focus on the firm's capability in translating revenue into profits at innumerable phases of measurement. On the other hand, profitability ratios that illustrate returns denote the firm's capability to take measurement of the general efficiency and effectiveness to generate returns to the owners. In the case of bank returns, ratios are well-thought-out to judge its profitability (Collins, 1999; Moody, 2017).

One of the tasks of this study, therefore, is to verify empirically the degree to which e-banking payment instruments have aided the financial and non-financial performance of the DMBs operating in Nigeria.

\subsubsection{Electronic Banking (e-Banking)}

The term e-banking describes the manner in which bank customer carries out banking dealings by way of electronic usages. This kind of banking majorly employs the use of internet as a means of delivery services of banking activities. The activities that bank customers can carry out are classified as transactional and nontransactional. Thus, e-banking (also known as online banking, internet banking) is an electronic payment method which permits customers of a bank or other financial institutions to carry out various financial transactions over the financial institution's website, Nickel (2018). In another fashion, Daniel (2010) states that e-banking is an automated delivery of new and traditional banking services and products straight to clients by way of electronic, interactive and communication networks or means.

Whether or not e-banking payment instruments are a stimulus or a drag on the performance of the DMBs operating in Nigeria would be empirically established in the paper. 


\subsubsection{Automated Teller Machines (ATMS)}

The plain system of non-branch bank is the ATM, which enables bank customers to check their balances and make withdrawal of money with the aid of their cards and secret pins. The ATM is a complex technology that is not accredited to a particular inventor. In other words, the present day ATMs used by clients are combinations of various inventions. Today's ATMs are sophisticated computers that are capable of performing what a bank cashier can, thereby ushering a paradigm shift from old to new era in banking services (Boateng, Amponsah, \& Serwaa-Adomako, 2014).

One of the issues to be resolved empirically in the paper is the contribution of the use of ATMs on the performance of the DMBs for the period 2009 to 2017.

\subsubsection{Mobile Banking (MB)}

Phone banking and mobile banking are parts of classical and recent days developments of the phones. Phone banking as a form of banking associated with a situation by which a phone was used by customer to call the bank about their balance and with some initial question(s) asked to verify caller was the rightful holder of the account; make payment, and effect transfers. These days, the mobile phone seems to be the most effective means of e-banking since the customer himself carries out operations on his phone. It can be used and applied ubiquitously as at today; also customers appear to have confidence and secure with its usage. It has similarity with the PC banking except that it is a smaller machine that is a $24 / 7$ operation through which the client is able to pay, transfer and check balances without a particular time or place. Hence, Tiwari, Buse, and Herstatt (2006) defined mobile banking as a form of transaction which entails the transference of rights of owner to use goods and services that is originated and/or accomplished by using mobile to computer-mediated networks through the assistance of an electronic device. Furthermore, mobile banking denotes a situation of providing bank-related financial services through the assistance of mobile telecommunication devices. In this sense, AlJabri and Sohail (2012) asserted that mobile banking is mostly executed through SMS or mobile internet, but as well be utilized by distinctive programs known as 'clients' downloaded to the mobile device. Thus, mobile banking is an arrangement that permits clients of a financial institution to carry out various financial transactions via a mobile device like mobile phone or tablet (Darrat, 1999).

\subsubsection{Point of Sale (POS)}

POS stands for "Point of sale". A POS system is used to carry out sales at brick \& mortar and e-commerce stores, (http://www.vineulumgroup.com/pos-system-key-features). In other words, the POS is a device that can be used in a particular time and place in which a small transaction is accomplished. Businesses of different types are gradually adopting POS systems at increasing rate, and basic explanation deduced is that a POS system abandons price tags method (http://en.wikipedia.org/wiki/point-of-sale). A sales price of item or product is connected to code of an item when summing stock, so the cashier basically needs to scan this code to process a sale. Where there is a case of price changes, it can be adjusted with ease through the inventory window. Additional benefits of POS comprise the ability to undertake different kinds of discounts, a loyalty scheme for clients, and more efficient stock control.

Since DMBs are the issuers of POS in Nigeria, it is thought germane to estimate empirically the contribution of POS usage to DMBs' performance.

\subsubsection{Web Banking (WB)}

Web banking, mostly called online or internet banking permits a user to conduct financial transactions via the internet (Frankenfield, 2019). It traditionally provides bank clients with every available service via a local branch such as transfers, bill payments and deposit. Every bank has its specially designed online banking, which are accessible both on desktop versions and via mobile apps. Web banking enables banks customers to transact conveniently - at home, at work, or on the go without necessarily visiting branch of the bank to perfect vital banking transactions.

Web banking can only be conducted with the use of a computer or other device, internet connectivity, and a bank or a debit card. To be accessible to service, customers are required to perfect proper registration of their online banking with a secret password created for the purpose. On completion of the online registration which varies from bank to bank enables customers to utilize their banking transactions using the service. Apart from some essential banks services like transfers and bill payments, it allows customers of a bank to open another accounts and as well have the opportunity to make application for credit facility through the online banking portals. Some useful benefits of web banking consist of giving orders for checks, placing stop to payments or checks, or immediate report of changes to address.

One of the issues to be examined empirically in the paper is the extent to which web banking has contributed to DMBs' performance in Nigeria.

\subsubsection{Return on Assets (ROA)}

ROA is commonly used to compare the financial performance of banks (Khrawish \& Mousa, 2011) because it shows the profit per unit of invested assets. In other words, ROA shows the percentage return generated by 
assets. When the ratio is higher, it means that the management is efficiently utilizing its assets. The ratio indicates how many Naira of earnings the bank derives from each naira of assets it controls. This seems a useful device for comparing the banks within the same industry (Collins, 1999; Moody, 2017). Thus, ROA is associated with asset management type of financial ratios and shows the extent a bank is profitable considering its total assets. It is calculated as: ROA = Net Income After Tax/ Total Assets (Collins, 1999; Moody, 2017). It is appropriate to evaluate ROA in contrast to a company's previous ROA numbers or the ROA of similar companies.

How far e-banking payment instruments have impacted on the expansion of the ROA remains an issue to be resolved empirically in the paper.

\subsubsection{Return of Equity (ROE)}

ROE shows the extent a firm is profitable by assessing the net income in relation to shareholders' or owners' equity. It assesses what owners could receive for investing in the firm. The decision rule or rule of thumb is that the greater the ratio, the more efficient is management in utilizing its equity base, and the better the return to investors. ROE is calculated: $\mathrm{ROE}=$ Net Income after Taxes/Total Equity Capital Account (Collins, 1999; Moody, 2017). In this sense, ROE is concerned with efficiency than profitability. A rising ROE signifies how a firm increases effort or ability to generate profit without necessarily focusing on much capital. It also shows the manner in which a firm's management can deploy the shareholders' fund or equity capital. As a matter of fact, firms normally strive to achieve a higher ROE. Decreasing ROE is usually an indication of likely problem occurring. In general, company's financial outcomes are interpreted in a careful manner and professionally in skills and expertise. Besides, it offers a foundation for evaluating the internal and external performances of the company (Lucey, 2003). Performance indicators are beneficial to the users if they bear a true reflection of the association that it was intended to test and useful for decision making.

The extent to which e-banking payment instruments have affected DMBs' performance in Nigeria would be estimated empirically in the paper.

\subsection{Empirical Literature}

Many researchers have undertaken studies on the impact of e-banking on the performance of banks in different countries. For example, Ngango, Mbabazize, and Shukla (2015) investigated the contribution of ebanking on the performance of banks in Rwanda, by employing combination of primary and secondary data. The results of their investigations showed that instruments such as ATM, pay direct, e-check conversion, mobile phone banking and e-transact exerted a significant impact on bank performance in the country especially as these instruments assisted to increase bank profitability, reduce bank cost of operations, rise in bank asset as well as bank efficiency. In a similar vein, Al-Smadi and Al-Wabel (2011) conducted a study in relation to the impact of e-banking on the performance of banks in Jordan for the period 2000-2010. The findings of their study showed that e-banking appeared with a negative impact on the performance. According to the authors, the cost- associated with the adoption of e-banking was still higher than revenues derived from the provision of e-bank services. Sana, Mohammad, Hassan, and Momina (2016) investigated the impact of ebanking on the profitability of Pakistani banks, using the interview survey research design. The results of their study revealed that e-banking has improved the profitability of banks - the system has facilitated cost reduction and earn profit within a short period of time. Abdullahi and Nyaoga (2017) carried out a study on the impact of the usage of the ATM on the performance of commercial banks in Nakuru County of Kenya, using 28 branch banks. The authors utilized both the correlations and regression analyses to conduct their study. The result of their study indicated that ATM usage exerted a significant and positive relationship on the operational performance of commercial banks in the country.

Many studies have investigated the impact of e-banking payments instruments on bank performance in Nigeria since their introduction over a decade ago. For example, Hassan, Mamman, and Fariuk (2013) conducted a study on the influence of e-banking products on the performance of the DMBs in Nigeria. Their findings showed that e-mobile and ATM transactions exerted a strong and significant impact on bank performance in Nigeria, while e-direct and SMS alerts recorded a negative impact on the six (6) banks surveyed. They, therefore, concluded that more awareness is created to enable the customers of DMBs benefit from the numerous advantages of using the e-mobile services and, hence, increase bank performance in the process. In a similar vein, Abaenewe, Ogbulu, and Ndugbu (2013) examined the profitability performance of MBs in Nigeria following the full adoption of e-banking system. The findings of the study revealed that the adoption of e-banking has positively and significantly improved the return on equity (ROE) of DMBs but exerted a negative impact of ROA. Further, Okoro (2014) examined the effects of selected e-payment instruments on the intermediation efficiency of the DMBs operation in Nigeria. Outcome of his study showed that ATM. POS, e-Mobile, web-banking positively and significantly affected DMBs' intermediation efficiency for the period covered by his study. Mussa, Kurfib, and Hassan (2015) conducted a study on impact of ebanking on the performance of DMBs in Nigeria. Their finding showed that DMBs' main motive of adopting the e-banking approach was to increase their clientage as well as retaining existing customers. Jenevive and Anyanwaokoro (2017) investigated the effects of e-payments on DMBs' profitability for the period 2009 to 
2015. Their results revealed that the coefficients of ATM and e-mobile appeared with a significant impact on DMBs' performance, while POS exerted a negative impact on DMBs' performance.

Given the foregoing review, it becomes expedient to establish empirically whether or not e-banking payment instruments have any impact on DMBs' performance in Nigeria.

\section{Theoretical Framework and Model Specification}

3.1. Theoretical Framework

The basic theoretical framework upon which the paper is hinged is the Transactions Cost Innovative Theory. The theory was propagated by Hicks and Niehans (1983) state that basic facet of financial innovation is essentially on ability to reduce the costs of transactions that respond to the advancement in technology and thereby resulting in reduced transactions costs. Thus, the ability of banks to lower their costs of transaction can assist in enhancement of innovation and upgrading of financial services and products and hence reduces the costs of making transactions. In other words, the adoption of e-banking by DMBs in Nigeria has considerably lessened their exchange costs and further enhanced the quality of their deliveries through technology advancement.

The quarterly data utilized for the paper were collected from the Central Bank of Nigeria (2017) and covered the period 2009 to 2017 - 36 observations. The Fully Modified Ordinary Least Squares (FMOLS) was employed to estimate the model of the paper. This method was originally intended towards provision of best estimates of co-integration regressions (Phillips \& Hansen, 1990) and employs kernel estimators of the nuisance parameters that affect the asymptotic distribution of the OLS estimator. The choice of the FMOLS stems from the fact that it has the advantage of modifying the least squares to explain serial correlation efficacies and test for the endogeneity in the regressors because of the presence of co-integrating relationships. Further, the technique requires at least a single co-integrating relationship among the series.

\subsection{Model Specification}

The paper used the multiple regression analysis to capture the association among bank performance and e-banking instruments, including the automated teller machine (ATM), point of sale (POS), mobile banking $(\mathrm{MB})$ and web banking (WB). Thus, the model specified for the paper is presented, thus:

$$
B P=f(A T M, P O S, M B, W B)
$$

Where: $\mathrm{BP}=$ Bank Performance; ATM = Automated Teller Machine; POS = Point of Sale; MB = Mobile Banking; WB =Web Banking.

Putting Equation 1 into an econometric form yields:

$$
B P_{t}=\beta_{0}+\beta_{1} A T M+\beta_{2} P O S+\beta_{3} M B+\beta_{4} W B+\mu t
$$

Since bank performance would be decomposed into measures of return on assets (ROA), return on equity (ROE) and net profit margin (NPM), Equation 2 will be re-written, thus:

$$
B P t=\beta O+\beta_{1} A T M+\beta_{2} P O S \beta_{3} M B+\beta_{4} W B+\beta_{5} R O A+\beta_{6} R O E+\beta_{7} N P M+\mu t
$$

Where:

$$
\begin{aligned}
& \mathrm{BP}=\text { Bank performance. } \\
& \beta_{0}=\text { Intercept. } \\
& \beta_{1}-\beta_{6}=\text { Coefficients of the independent variables. } \\
& \mathrm{U}_{\mathrm{t}}=\text { Stochastic term. }
\end{aligned}
$$

\subsection{Unit Root Test}

The estimation exercise of this paper was carried out in three stages. First, unit root testing employing Augmented Dickey-Fuller (ADF) test, to ascertain their long-run characteristics - that is, the level at which the variables became stationary. The test which was conducted via the Augmented Dickey-Fuller (ADF) approach is specified, thus:

$$
\Delta X_{t}=\lambda_{1} X_{t-1}+\lambda_{2} T+\sum_{i=1}^{n} \varphi i \Delta X_{t-1}+\epsilon_{t}, \epsilon_{t} I I D\left(0, \sigma^{2}\right)
$$

Where the Equation 4 indicates: $\Delta$ as "the difference operator"; $X$ as "the natural logarithm of the series"; T as "the trend variable", $\lambda$ and $\varphi$ are "the parameters to be estimated"; and, $\epsilon$ is "the error term, which is independently and identically distributed with zero mean and constant variance". Hence, it eventually adjusts the error terms by putting the lagged difference terms of the regressand (Engle \& Granger, 1987). The stationarity test gives avenue for the determination of the order of integration of variables used in the model. Importantly, if the variables are integrated into different orders, then give room for co-integration. 
Second, the residuals obtained from estimating the model for stationarity were utilized to test for the existence of long-run relationship among the dependent and explanatory variables. This became paramount to guarantee the existence of a long-run relationship between the dependent and explanatory variables of the paper's model.

Third, the short-run dynamics of the Fully Modified Ordinary Least Squares (FMOLS) were estimated to provide for robust outcomes.

$$
\Delta Z_{t}=\varphi_{0}+\pi Z_{t-p}+\sum_{i=1}^{p-1} \varphi i \Delta Z_{t-1}+\epsilon_{t} \epsilon_{t} I I D\left(0, \sigma^{2}\right)
$$

In Equation $5, " \Delta Z_{t}$ and $\Delta Z_{t-1}$ are vectors and are of 1(1) variables, $\varphi i$ and $\pi$ are the matrices of parameters estimated using OLS, and $\epsilon_{t_{i}}$ is the Gaussian random variable. The rank, $\pi$, determines the longrun equilibrium relationship amongst the variables and is sometimes represented by $\mathbf{r}$, the component $\pi Z_{t-p}$ produces different linear combinations of the levels of the time series $Z_{t}$. The model shows that if the rank of the coefficient matrix $\pi$ is 1 , or greater than 1, there exist one or more co-integrating vectors; hence, there is long-run relationship among the series of the model”. Since the co-integration test is sensitive by the choice of lag-length, we conduct the test for optimal lag length. This helps to obtain the lag-length that appropriately specifies co-integration estimation.

\section{Data Analysis and Interpretation of Results}

The time-series data of the paper are contained in Appendix I to the paper.

Empirical results of the paper's regression exercise are contained in this section in a sequential order, thus: descriptive statistics results, unit root test results, co-integration results and the results of the short-run dynamics.

\subsection{Descriptive Statistics}

The descriptive statistics obtained for the paper are presented in Table 1, thus:

\begin{tabular}{l|c|c|c|c|c|c|c|c}
\multicolumn{8}{c}{ Table-1. Descriptive Statistics. } \\
\hline $\begin{array}{l}\text { Statistical } \\
\text { tools }\end{array}$ & ATM & MB & POS & WB & TDD & ROA & ROE & NPM \\
\hline Mean & 773.07 & 5150.1 & 79.02 & 21.1 & 8706318 & 2.96 & 15.78 & 54.87 \\
\hline Median & 702.16 & 3142 & 37.04 & 17.8 & 8441747 & 2.42 & 1.221 & 60.48 \\
\hline Maximum & 1790 & 14092 & 393.1 & 61.7 & 12782017 & 8.9 & 259.7 & 67.99 \\
\hline Minimum & 62.59 & 6 & 1.865 & 3.37 & 4569149 & 0.09 & -223 & 31 \\
\hline Std. Dev. & 533.85 & 5035.3 & 95.69 & 16.1 & 2723506 & 2.01 & 114.1 & 12.63 \\
\hline Skewness & 0.3498 & 0.3415 & 1.48 & 1.08 & 0.099006 & 1.52 & 0.485 & -0.762 \\
\hline Kurtosis & 1.9547 & 1.4892 & 4.804 & 3.33 & 1.562956 & 5.49 & 4.077 & 1.992 \\
\hline Jarque-Bera & 2.3729 & 4.1234 & 18.02 & 7.02 & 3.156455 & 23.2 & 3.153 & 5.003 \\
\hline Probability & 0.3053 & 0.1272 & $1 \mathrm{E}-04$ & 0.03 & 0.206341 & 0 & 0.207 & 0.082 \\
\hline Observations & 36 & 36 & 36 & 36 & 36 & 36 & 36 & 36 \\
\hline
\end{tabular}

From Table 1, it can be observed that the values obtained for mean and median in respect of ROE, ROA, ATM, MB, POS, and TDD have the problems of the outliers since the values obtained for the mean are greater than those obtained for median. This is confirmed by the values obtained for standard deviation in those series. The values for skewness, except for NPM, are positive - implying that the series are normally distributed.

The values of Kurtosis for ROA, ROE and POS are greater than 3; evidencing that these series are normally distributed. In a similar vein, series such as ATM, MB, electronic funds transfer, NPM and TDD are normally distributed. All the pro-values of Jarque Bera statistics are greater than 0.05 per cent level of significance. For ROA, ROE and WB which have pro-values of the Jarque Bera statistics less than the 0.01 per cent level of significance, it cannot be said that they are not normally distributed because of the values obtained in Kurtosis.

\subsection{Econometrics Results}

The econometrics estimations exercise was conducted in three states as follows: unit root test, cointegration test, and the short-run dynamical estimations. The unit root test results are shown in Table 2 , thus: 
Table-2. Unit roots tests results.

\begin{tabular}{l|l|c|c|c}
\hline Variables & Level/Difference & Critical value (ADF) & ADF & ORDER \\
\hline ROA & Level & -2.9640 & -3.1720 & \\
\hline & First Diff & -2.9571 & $-4.7064^{*}$ & $1(1)$ \\
\hline ROE & Level & -2.9677 & -2.0933 & \\
\hline NPM & First Diff. & -2.9862 & $-47.107^{*}$ & $1(1)$ \\
\hline & Level & -2.9484 & -2.3855 & \\
\hline TDD & First Diff. & -2.9511 & $-6.9807^{*}$ & $1(1)$ \\
\hline ATM & Level & -3.0989 & -7.1621 & \\
\hline & First Diff. & -3.2127 & $-6.1184^{*}$ & $1(1)$ \\
\hline WB & Level & -3.0989 & -1.2363 & \\
\hline & First Diff. & -3.1199 & $-4.4003^{*}$ & $1(1)$ \\
\hline MBK & Level & -2.9484 & -2.6829 & \\
\hline POS & First Diff. & -2.9511 & $-6.1995^{*}$ & $1(1)$ \\
\hline & Level & -3.1199 & -2.7825 & \\
\hline Note: indicates significance at $5 \%$ level. & -3.2127 & $-8.4365^{*}$ & $1(1)$ \\
\hline & First Diff. & -2.9484 & -1.3173 & $1(1)$ \\
\hline
\end{tabular}

As the results in Table 2 have shown, all the series were non-stationary in their level forms $\mathrm{I}(\mathrm{O})$ but became stationary at first difference I(1). The residuals of the unit root tests were used to conduct the cointegration test, the results of which are reported in Table 3, thus:

Table-3. Summary of co-integration residual based test

\begin{tabular}{|c|c|c|c|c|c|}
\hline $\mathrm{ROA}$ & $\begin{array}{l}\text { ROA, ATM, EFT, } \\
\text { MBK, POS }\end{array}$ & -3.7418 & -2.9766 & 0.0086 & Cointegrated \\
\hline $\mathrm{ROE}$ & $\begin{array}{l}\text { ROE, ATM, EFT, } \\
\text { MBK, POS }\end{array}$ & -3.0920 & -2.9484 & 0.0364 & Cointegrated \\
\hline NPM & $\begin{array}{l}\text { MPM, ATM, EFT, } \\
\text { MBK, POS }\end{array}$ & -3.7055 & -2.9484 & 0.0083 & Cointegrated \\
\hline LTDP & $\begin{array}{l}\text { LTDP, ATM, EFT, } \\
\text { MBK, POS }\end{array}$ & -3.8352 & -2.9484 & 0.0060 & Cointegrated \\
\hline
\end{tabular}

Note: Significant at the $5 \%$ level.

Table-4. Short run OLS

\begin{tabular}{|c|c|c|c|c|}
\hline Variables & ROA & ROE & NPM & LTDP \\
\hline & Column I & Column II & Column III & Column IV \\
\hline \multirow[t]{2}{*}{ Constant } & -0.1398 & -3.7766 & 1.5124 & 0.0319 \\
\hline & $(-0.7662)$ & $(-0.3007)$ & $(1.0783)$ & $(4.0035)$ \\
\hline \multirow[t]{2}{*}{$\mathrm{D}(\mathrm{ATM})$} & -2.2622 & $140.8548^{*}$ & -9.8228 & \\
\hline & $(-2.7793)$ & $(2.5804)$ & $(-1.4433)$ & \\
\hline \multirow[t]{2}{*}{$\mathrm{D}(\mathrm{POS})$} & $-1.0080^{*}$ & & 3.6070 & \\
\hline & $(2.5827)$ & & $(0.7842)$ & \\
\hline \multirow[t]{2}{*}{$\mathrm{D}(\mathrm{MB})$} & & & $-6.1871^{*}$ & \\
\hline & & & $(-1.5426)$ & \\
\hline \multirow[t]{2}{*}{$\mathrm{D}(\mathrm{WB})$} & & & $5.9032^{*}$ & \\
\hline & & & $(2.2051)$ & \\
\hline \multirow[t]{2}{*}{$\mathrm{D}(\mathrm{ATM}(-1)$} & & & & $-0.0814^{*}$ \\
\hline & & & & $(-2.2253)$ \\
\hline \multirow[t]{2}{*}{$\mathrm{D}(\mathrm{WB}(-1)$} & $0.8082^{*}$ & $-48.9716^{*}$ & & 0.00458 \\
\hline & $(3.0013)$ & $(-2.6003)$ & & $(3.2313)$ \\
\hline \multirow[t]{2}{*}{$\operatorname{ECM}(-1)$} & $-0.6406^{*}$ & $-0.4706^{*}$ & $-0.6744^{*}$ & $-0.2766^{*}$ \\
\hline & $(-3.5464)$ & $(-3.5090)$ & $(-4.2135)$ & $(-2.8682)$ \\
\hline $\mathrm{R}^{2}$ & 0.5338 & 0.5002 & 0.5382 & 0.4648 \\
\hline Adjusted $\mathrm{R}^{2}$ & 0.4695 & 0.4520 & 0.4583 & 0.4114 \\
\hline DW Statistics & 1.9250 & 1.9797 & 1.8749 & 1.5771 \\
\hline F-Statistics & 8.3012 & 10.0106 & 6.7589 & 8.6876 \\
\hline Prob(F-Statistics) & 0.0001 & 0.0009 & 0.0002 & 0.0002 \\
\hline
\end{tabular}


The co-integration test was carried out via the residual-based approach on each of the models and the results reported in Table 3 showed that all the series in each of the models are co-integrated, that is, they have a long-run relationship. Hence, the short-run estimation was carried out using the FMOLS was deployed to estimate the short-run dynamics of the model specified for the paper. Table 4 shows the results of OLS estimation.

It is important to explain here that the performance of the DMBs in Nigeria is decomposed into ROA, ROE, NPM and TDD. In column 1, ROA captures the performance of the DMBs. The coefficient of determination, $\mathrm{R} 2$, is 0.5338 which suggests that over $53 \%$ of the systematic variations in DMBs' ROA have been explained by the set of the explained independent variables. The value of the F-statistic, 8.3012 [0.0001] indicates that the model of the paper has an overall significance at the traditional $1 \%$ level. The DW-statistic has a value of 1.9250 and this empirical evidence indicates that there is a weak presence of serial correlation in the model specified for the paper. Specifically worthy of note, however, is the sign and statistical significance of the coefficient of the error correction, $\operatorname{ECM}(-1)-0.6406$ and indicates that about $64.07 \%$ of the errors in the previous times' disequilibrium have been corrected. The negative sign of the coefficient accords with the presumptive sign and suggests that temporary deviations from the equilibrium value of the data series of DMBs' performance are eliminated. Accordingly, it is possible to re-establish the long-run equilibrium state. In other words, the error correction specification suggests the existence of the possibility of convergence of predictions of the behavior of DMBs' performance in Nigeria to its long-run equilibrium value. The coefficient of ATM is 2.2622 and does not conform to a-priori expectation but is significant at the $5 \%$ level. This indicates that a $1 \%$ change in the use of ATM reduces ROA by $2.26 \%$.

The coefficient of POS is -1.0080 and does not conform to a-priori expectation but is significant at the $5 \%$ level. This empirical finding indicates that a $1 \%$ change in POS usage reduces ROA by $1,008 \%$. The coefficient of lagged WB is 0.8082 and conforms to a-priori expectation; it is significant at the $5 \%$ level. This empirical finding suggests that a $1 \%$ change in WB usage reduces ROA by $2.26 \%$.

In column 2, ROE comes as an indicator of the performance of DMBs. The coefficient of determination is 0.5002 and implies that about $50.02 \%$ of the systematic variations in ROE have been accounted for by the explanatory variables. The F-statistic is 10.0107 [0.0009] and shows that the model is statistically significant at the $5 \%$ level. The coefficient of ECM is -0.4706 and indicates that $47.06 \%$ of the errors in previous times' disequilibrium have been corrected.

The coefficient of ATM is 140.8548 and conforms to a-priori expectation. This empirical finding is positive and significant at the $5 \%$ level and suggests that a $1 \%$ change in the volume and value of ATM increases ROE by $140.85 \%$ in the current period. The coefficient the lagged WB is -48.9710 and does not conform to a-priori expectation but significant at the $5 \%$ level. The implication for this empirical result is that a $1 \%$ change in the volume and value of $\mathrm{WB}$ in the previous period reduces ROE by $48.97 \%$.

In column 3, DMBs' performance is denoted by NPM. The coefficient of determination is 0.5382 and this suggests that about $53.82 \%$ of the systematic variations in NPM have been explained by the explanatory variables. The value of F-statistic is 6.7589 [0.0002] and suggests that the estimated model has an overall significance at the traditional $1 \%$ level. The value of the ECM is -0.2766 and is correctly signed, that is, it conforms to a-priori expectation and is significant at the $5 \%$ level. The speed of adjustment, -0.6745 , indicates that $67.45 \%$ of the errors in the previous disequilibrium has been corrected in the current period.

The value of the coefficient of ATM, -9.8228, is negative but significant at the $5 \%$ level. It does not conform to the expected sign. This empirical finding indicates that ATM harms the NPM of DMBs. Impliedly, a $1 \%$ increase in the volume and value of ATM transactions in the current period reduces NPM by $9.822 \%$. The coefficient of WB is 5.90325 and conforms to a-priori expectation; it is significant at the $5 \%$ level. The coefficient of $\mathrm{MB}$ is -6.1871 . Although it is significant at the $5 \%$ level, it does not have the expected sign. This finding signifies that MB harms NPM in the period under review. Hence, a 1\% increase in MB leads $6.1871 \%$ decrease in NPM in the current period. In terms of POS, the coefficient is 3.6070 in the current period. This finding suggests that a $1 \%$ increase in the volume and value of MB transactions translates into $3.6070 \%$ of the DMBs' NPM.

The last column which is column 4 has the log of total DMBs' deposits (TDD). The coefficient of determination is 0.4649 and revealed that $46.49 \%$ of the systematic variations in TDD have been explained by all the explanatory variables. The F-statistic of 8.6876[0.0002] suggests that the estimated model is statistically significant at the traditional $1 \%$ level. The DW-statistic of 1.5771 indicates the presence of autocorrelations since the value $<2$. The value of ECM, -0.2767 and indicates that $27.67 \%$ of the errors in the previous period have been corrected. The coefficients of lagged ATM, -0.0814, and WB, 0.04580, are significant at the $5 \%$ level. Thus, a $1 \%$ change in the volume and value of ATM decreases TDD by $0.0814 \%$ and the WB $0.0458 \%$, respectively.

Interestingly, the FMOLS approach was further utilized to provide some robust estimation for the analysis. The empirical results of the FMOLS are reported in Table 5, thus: 
Table-5. Short run FMOLS

\begin{tabular}{|c|c|c|c|c|}
\hline Variables & ROA & ROE & NPM & LTDD \\
\hline & Column I & Column II & Column III & Column IV \\
\hline \multirow[t]{2}{*}{ Constant } & 0.09728 & -3.0076 & 1.2835 & 0.03300 \\
\hline & $(0.5931)$ & $(-0.4626)$ & $(1.0015)$ & $(4.5915)$ \\
\hline \multirow[t]{2}{*}{$\mathrm{D}(\mathrm{ATM})$} & $-3.3735^{*}$ & $157.3148^{*}$ & $-10.0605^{*}$ & \\
\hline & $(-3.5435)$ & $(5.7041)$ & $\begin{array}{l}(-1.6021) \\
-8.1147^{*} \\
(-2.0269)\end{array}$ & \\
\hline \multirow[t]{2}{*}{$\mathrm{D}(\mathrm{WB})$} & $1.0088^{*}$ & & $6.3100^{*}$ & \\
\hline & $(2.3490)$ & & $(2.5346)$ & \\
\hline \multirow[t]{2}{*}{$\mathrm{D}(\mathrm{POS})$} & & $-36.0116^{*}$ & 5.5265 & \\
\hline & & $(-2.7623)$ & $(1.2243)$ & \\
\hline \multirow[t]{2}{*}{$\mathrm{D}(\mathrm{ATM}(-1))$} & & & -0.0758 & $-0.07581^{*}$ \\
\hline & & & $(-2.3337)$ & $(-2.3380)$ \\
\hline \multirow[t]{2}{*}{$\mathrm{D}(\mathrm{LWB}(-1))$} & $0.9813^{*}$ & $-51.847 \mathrm{O}^{*}$ & 0.0403 & $0.04030^{*}$ \\
\hline & $(4.0898)$ & $(-5.5219)$ & $(3.2048)$ & $(3.2048)$ \\
\hline \multirow[t]{2}{*}{$\operatorname{ECM}(-1)$} & -0.3988 & -0.4857 & -0.5863 & $-2.2682^{*}$ \\
\hline & $(-2.5521)$ & $(-7.3966)$ & $(-4.2136)$ & $(-3.1243)$ \\
\hline $\mathrm{R}^{2}$ & 0.5338 & 0.5153 & 0.5628 & 0.4766 \\
\hline Adjusted $\mathrm{R}^{2}$ & 0.4695 & 0.4461 & 0.4848 & 0.4224 \\
\hline
\end{tabular}

The essence of carrying the FMOLS estimations is to ensure that estimations are free from endogeneity and serial correlation. A close look at each of the columns in Table 5 will reveal that correcting for serial correlation and endogeneity has led to some of the variables changing signs and the coefficients of determination also have moderate changes.

The estimation exercise of this paper also carried out post-diagnostic tests, the results of which are contained in Table 6, thus:

Table-6. Post-diagnostic test.

\begin{tabular}{l|c|c|c|c}
\multicolumn{5}{c}{ Table-6. Post-diagnostic test. } \\
\hline Variables & ROA & ROE & NPM & LTDP \\
\hline Jarque Bera & Column I & Column II & Column III & Column IV \\
& 30.0108 & 19.0165 & 0.04975 & 1.7745 \\
& $(0.0000)$ & $(0.0001)$ & $(0.9754)$ & $(0.4118)$ \\
\hline Breusch-Godfrey Serial & 0.2452 & 0.3916 & 0.0201 & 0.6006 \\
Correlation LM & $(0.7843)$ & $(0.6796)$ & & $(0.5145)$ \\
\hline Heteroskedasticity(Breusch- & 0.1926 & 2.1517 & 0.8832 & 0.1797 \\
Pagan-Godfrey) & $(0.9404)$ & $(0.1145)$ & $(0.1280)$ & $(0.9096)$ \\
\hline CUSUM Test (See Appendix Six) & Stable & Stable & Stable & Stable \\
\hline CUSUM Test (See Appendix Six) & Not Stable & Not Stable & Stable & Stable \\
\hline Note: *Significant at $5 \%$ level; Probability in parenthesis.
\end{tabular}

The results obtained from the post-diagnostic tests revealed that some statistics require certain comments. For example, the normality test using the Jarque Bera statistics showed that the residuals are normally distributed at the 5\% level of significance and hence can be used for in inference for NPM and TDD. In serial correlation test using Breusch-Godfrey serial correlation LM except for ROA and ROE, the results showed that all the residuals are not serially correlated at the $5 \%$ level of significance. The same results are obtained for Heteroskedasticity test using Breusch-Pagan-Godfrey approach. The results thus obtained signified that the coefficients in each of the models are stable at the $5 \%$ level of significance. Lastly, the sum of squares show that the coefficients in each of the models are stable at the $5 \%$ level of significance except in column 1 and column 2, where ROA and ROE are not stable.

\section{Summary, Conclusion and Recommendations}

The paper conducted an in-depth examination of the impact of e-banking payment instruments on the financial performance of the DMBs in Nigeria, using quarterly data for the period 2009 to 2017 . The fully modified OLS was utilized to estimate the effects of ATM, POS, WB, and MB on the performance of the 21 DMBs operating in Nigeria. Bank performance in the paper was denoted by ROA, ROE and NPM. Some of the major findings of the paper revealed that ATM exerted a negative effect on ROA but was significant at the $5 \%$ level; exerted a positive and significant effect on ROE at the $5 \%$ level, and negative effect on NPM at the $5 \%$ level. POS exerted a negative effect on ROE but was significant at the $5 \%$ level; it exerted a positive and significant on NPM; WB exerted a positive and significant effect on ROA and NPM at the 5\% level. These 
findings were robust and impressive since the values of the $\operatorname{ECM}(-1),-0.3988 .-0.4857,-0.5863$ and -22682 appeared with the right signs. The coefficients of determination, $\mathrm{R} 2$, in the three columns showed that all the independent variables were able to explain over $50 \%$ of the systematic variations in the dependent variables.

Thus, the paper strongly recommended that all the DMBs operating in Nigeria keep adopting and using e-banking payment instruments in their operations to continually enhance the quality of their products and services thereby increasing their performance.

\section{References}

Abaenewe, Z. C., Ogbulu, O. M., \& Ndugbu, M. O. (2013). Electronic banking and bank performance in Nigeria. West African Journal of Industrial and Academic Research, 6(1), 171-187.

Abdullahi, H. M., \& Nyaoga, R. B. (2017). Machines usage on operational performance of commercial banks in Nakuru County, Kenya. Kenya International Journal of Economics, Finance and Management Sciences, 5(3), 162-167. Available at: https://doi.org/10.11648/j.ijefm.20170503.14.

Al-Jabri, I. M., \& Sohail, M. S. (2012). Mobile banking adoption: Application of diffusion of innovation theory. Journal of Electronic Commerce Research, 13(4), 379-391.

Al-Smadi, M. O., \& Al-Wabel, S. A. (2011). The impact of electronic banking on the performance of Jordanian Bank. Journal of Internet Banking and Commerce, 16(2), 1-10.

Bellis, M. (2019). History of automatic teller machines or ATM. Retrieved from: https:www.thoughtco.com/automaticteller-machines-atm-1991236.

Boateng, E., Amponsah, M., \& Serwaa-Adomako, A. (2014). Impact assessment of ATM on customer satisfaction of banks in Ghana: A case study if Kumasi, Ghana. ADRRI Journal of Arts and Social Sciences, 7(1), 21-30.

Central Bank of Nigeria. (2017). Statistical bulletin (Vol. 28). Abuja Nigeria: Central Bank of Nigeria.

Collins, P. H. (1999). Dictionary of banking and finance (2nd ed.). Middlesex: Peter Collins.

Daniel, E. (2010). Provision of electronic banking in the UK and the Republic of Ireland. International Journal of Banking Marketing, 17(2), 72-82.

Darrat, A. F. (1999). Are financial deepening and economic growth causally related? Another look at the evidence. International Economic Journal, 13(3), 19-35. Available at: https://doi.org/10.1080/10168739900000002.

Engle, R. F., \& Granger, C. W. (1987). Co-integration and error correction: Representation, estimation and testing. Econometrica, 55(2), 251-276. Available at: https://doi.org/10.2307/1913236.

Floss, M. (2013). A brief history of the ATM. Rerieved from mentalfloss.com/article/.../brief-history-at. [Accessed May 16. 2018 ].

Frankenfield, J. (2019). Online banking. Retrieved from: https://www.investopedia.com/terms/o/onlinebanking.asp.

Hassan, S. U., Mamman, A., \& Fariuk, M. A. (2013). Electronic banking products and performance of Nigerian listed deposit money banks. American Journal of Computer Technology and Application, 1(10), 38-148.

Hicks, D., \& Niehans, J. (1983). Financial innovation, multinational banking and monetary policy. Journal of Banking and Finance, 7(4), 537-551. Available at: https://doi.org/10.1016/0378-4266(83)90011-0.

Jenevive, O., \& Anyanwaokoro, M. (2017). Eelectronic payment methods and profitability of banking firms in Nigeria: A panel data analysis. International Journal of Finance and Accounting, 6(3), 67-74.

Khrawish, H. A., \& Mousa, N. A. (2011). The impact of e-banking on bank profitability: Evidence from Jordan. Middle Eastern Finance and Economics, 13(1), 142-158.

Lucey, T. (2003). Costing (6th ed.). Padstow, Cornwall: TJ International.

Moody. (2017). Banking account and ratio definitions. Moody's Investors Service. Retrieved from: https://www.moodys.com/sites/products/productattachments/banking\%20account\%20and\%20ratio\%20definiti ons.pdf.

Mussa, A., Kurfib, S. A., \& Hassan, H. (2015). The impact of online banking on the performance of Nigerian banking sector. Paper presented at the Proceedings of the International Conference on E-Commerce, Kuching, Sarawak, Malaysia.

Ngango, A., Mbabazize, M., \& Shukla, J. (2015). E-Banking and performance of commercial banks in Rwanda: A case of Bank of Kigali. European Journal of Accounting Auditing and Finance Research, 3(4), 25-57.

Nickel, T. (2018). Advantages and disadvantages of internet banking. Retrieved from https://toughnickel.com/personalfinance/Advantages-and-Disadvantages-of-Internet-Banking. [Accessed 11 April 2018].

Okoro, A. (2014). Impact of electronic banking instruments on the intermediation efficiency of the Nigerian economy. International Journal of Accounting Research, 42(1480), 1-8.

Phillips, P. C., \& Hansen, B. E. (1990). Estimation and inference in models of cointegration: A simulation study. Advances in Econometrics, 8(1989), 225-248.

Sana, H. S., Mohammad, K. M., Hassan, H. S., \& Momina, A. (2016). The impact of e-banking on the profitability of banks: A study of Pakistani banks. Journal of Public Administration and Governance, 1(1), $31-38$.

Tiwari, R., Buse, S., \& Herstatt, C. (2006). Impact of mobile technologies on customer behavior and its implications for banks. Paper presented at the Working Paper No. 37, Presented at Portland International Conference on Management of Engineering and Technology, Instanbul. 
Appendix-1. Data of the Paper.

\begin{tabular}{|c|c|c|c|c|c|c|c|c|}
\hline Year & ATM & WB & MB & POS & TDD & ROA & ROE & NPM \\
\hline & & & & & & $\%$ & $\%$ & $\%$ \\
\hline \multicolumn{9}{|l|}{ 2009: } \\
\hline$Q_{1}$ & 137.72 & 4.38 & 0.06 & 3.51 & 4569149 & 4.34 & 24.3 & 51.51 \\
\hline$\widetilde{\mathrm{Q}}^{2}$ & 145.57 & 5.19 & 0.11 & 2.75 & 4292411 & 6.84 & -171 & 65.44 \\
\hline Q3 & 126.12 & 52.3 & 0.52 & 2.48 & 4585570 & 6.21 & -156 & 59.44 \\
\hline$\tilde{Q}^{4}$ & 139.19 & 22.3 & 0.58 & 2.29 & 5763511 & 8.9 & -223 & 36.79 \\
\hline \multicolumn{9}{|l|}{ 2010: } \\
\hline$Q_{1}$ & 62.59 & 3.37 & 0.87 & 2.77 & 5805455 & 8.9 & -223 & 36.79 \\
\hline $\mathrm{Q}^{2}$ & 80.72 & 4.26 & 1.37 & 2.67 & 5927508 & 3.64 & 239 & 36.2 \\
\hline$\widetilde{\mathrm{Q}} 3$ & 114.9 & 9.94 & 1.84 & 2.8 & 5983086 & 3.87 & 254 & 34.01 \\
\hline $\mathrm{Q}^{4}$ & 141.5 & 7.48 & 2.57 & 4.48 & 5954260 & 3.9 & 256 & 33.75 \\
\hline \multicolumn{9}{|l|}{ 2011: } \\
\hline Q1 & 333.51 & 24.1 & 3.32 & 6.28 & 5994451 & 3.96 & 260 & 33.26 \\
\hline$\tilde{\mathrm{Q}}^{2}$ & 364.67 & 22 & 3.72 & 6.45 & 6534832 & 3.59 & 236 & 36.62 \\
\hline Q3 & 387.48 & 6.36 & 5.01 & 8.64 & 6520957 & 0.09 & 0.43 & 36.4 \\
\hline$\widetilde{Q}^{4}$ & 476.08 & 7.11 & 6.93 & 9.65 & 6531913 & 0.1 & 0.5 & 31 \\
\hline \multicolumn{9}{|l|}{ 2012: } \\
\hline$Q^{1}$ & 454.79 & 6.38 & 1.08 & 1.87 & 6928388 & 0.1 & 0.49 & 67.99 \\
\hline$\widetilde{Q}^{2}$ & 483.25 & 6.93 & 4.93 & 8.74 & 6883439 & 2.39 & 13.1 & 67.75 \\
\hline Q3 & 499.71 & 7.53 & 7.26 & 14.7 & 6988347 & 2.9 & 13.1 & 67.7 \\
\hline$\tilde{Q}^{4}$ & 546.91 & 10.7 & 18.2 & 22.7 & 8062105 & 2.4 & 13.1 & 67.7 \\
\hline \multicolumn{9}{|l|}{ 2013: } \\
\hline $\mathrm{Q}_{1}$ & 611.26 & 11.4 & 22.9 & 26.3 & 8228180 & 2.4 & 13 & 62 \\
\hline$\widetilde{\mathrm{Q}}_{2}$ & 675.09 & 9.36 & 28.9 & 30.9 & 8649311 & 2.31 & 0.14 & 47.92 \\
\hline$\widetilde{Q}_{3}$ & 729.23 & 12.3 & 33.9 & 43.1 & 8276883 & 2.9 & 0.14 & 65.2 \\
\hline $\mathrm{Q}^{4}$ & 813.36 & 14.3 & 57.1 & 60.6 & 8606611 & 2.3 & 0.14 & 63.9 \\
\hline \multicolumn{9}{|l|}{ 2014: } \\
\hline Q1 & 784.05 & 16.6 & 66.4 & 67.5 & 8648463 & 2.3 & 0.14 & 63.9 \\
\hline$\widetilde{Q}^{2}$ & 852.36 & 14.1 & 74.2 & 70.3 & 9289136 & 1.88 & 0.17 & 53.63 \\
\hline Q3 & 1027.9 & 18.9 & 86.5 & 78 & 9621382 & 2.46 & 0.2 & 62.7 \\
\hline$\tilde{Q}^{4}$ & 1015.5 & 24.4 & 119 & 96.4 & 10489980 & 2.5 & 0.23 & 56.96 \\
\hline \multicolumn{9}{|l|}{ 2015: } \\
\hline $\mathrm{Q}_{1}$ & 1112 & 22.5 & 95 & 97.3 & 11793947 & 2.42 & 0.21 & 51.2 \\
\hline$\widetilde{Q}^{2}$ & 1140 & 21.9 & 97.6 & 117 & 12222871 & 2.43 & 1.22 & 65.22 \\
\hline Q3 & 1226.8 & 23.5 & 103 & 133 & 11895730 & 2.42 & 1.22 & 65 \\
\hline $\mathrm{Q}^{4}$ & 1292.4 & 26.1 & 116 & 162 & 11403218 & 2.5 & 0.38 & 65.54 \\
\hline \multicolumn{9}{|l|}{ 2016: } \\
\hline$Q_{1}$ & 1247.9 & 27.3 & 141 & 117 & 11380144 & 2.5 & 0.36 & 62.15 \\
\hline $\mathrm{Q}^{2}$ & 1363.9 & 26.6 & 86.4 & 136 & 12383370 & 1.26 & 1.79 & 61.45 \\
\hline Q3 & 1531.7 & 35.3 & 109 & 166 & 12782017 & 2.32 & 1.79 & 61.45 \\
\hline$\tilde{Q}^{4}$ & 1758.9 & 51.8 & 135 & 224 & 12146914 & 1.3 & 1.84 & 63.24 \\
\hline \multicolumn{9}{|l|}{ 2017: } \\
\hline$Q_{1}$ & 1790 & 55.2 & 126 & 266 & 11947890 & 1.27 & 1.73 & 67.57 \\
\hline $\mathrm{Q}^{2}$ & 1110 & 34.5 & 75.5 & 178 & 11603131 & 2.09 & 2.02 & 56.72 \\
\hline Q3 & 1553 & 61.7 & 117 & 393 & 11674719 & 2.42 & 2.06 & 57.75 \\
\hline $\mathrm{Q}^{4}$ & 1700.6 & 50.5 & 106 & 279 & 12758155 & 2.6 & 2.52 & 59.52 \\
\hline
\end{tabular}

Source: CBN, NBS, Financial Stability Report, Trading Economics. 